\title{
THE HISTOTOPOGRAPHIC FEATURES OF FORMATION OF KELOID SCARS OF MAXILLOFACIAL LOCALIZATION
}

DOI: 10.36740/WLek202003131

\author{
Kateryna P. Lokes', David S. Avetikov' ${ }^{1}$, Oksana V. Klitynska², Pavlo P. Brekhlichuk², Yana I. Bun² \\ 1 UKRAINIAN MEDICAL STOMATOLOGICAL ACADEMY, POLTAVA, UKRAINE \\ 2UZHHOROD NATIONAL UNIVERSITY, UZHHOROD, UKRAINE
}

\begin{abstract}
The aim: Study of the influence of local oxygen deficiency on the features of the formation of keloid scars of the head and neck.

Materials and methods: The research material was 17 incisional biopsy specimens of keloid scars, which were the highest age categories of patients from 19 to 63 years. Results: It was revealed that at coloring according to Mallory's technique, sections of fibrinoid swelling of collagen fibers were noted near central homogeneous hyaline masses. The lateral areas of the dermis that adjacent to keloid scar tissue, at coloring by the Hart method, in our modification, were characterized by the separation of the hyalinosis zone from the undamaged dermis by coarse bundles of elastic fibers that are colored in dark purple. The undifferentiated dysplasia of the connective tissue has caused the replacement and obstruction of single vascular components, which has complicated the local oxygen deficiency of keloid-altered tissues.

Conclusions: Thus, plasmaragia and the accumulation of protein deposits in the perivascular space determine the inhibition of local hemodynamics, which explains the decrease in oxygen transport to tissues. Decreased oxygenation and increased permeability of the vascular wall causes local hemocirculatory hypoxia.
\end{abstract}

KEY WORDS: keloid scar, hyalinosis, histopographic features

Wiad Lek. 2020;73(3):565-568

\section{INTRODUCTION}

Scars are visible and palpable skin changes that remain after healing various types of damage to the integrity of the skin. Scarring is a pathophysiological process of skin regeneration, which is directed at closing of defect. Atypical wound healing may be accompanied by excessive scarring. In this case, randomly (chaotically) located fibers of dense connective tissue form hypertrophic or keloid scars. The regulation of process of scar formation depends on many iatrogenic and somatic factors. The problem of excessive scar formation deserves a particular attention, primarily in the open areas of the human body [1-4].

Long-term treatment of wounds, purulent inflammatory processes, the presence of various pyogenic microorganisms in them, as well as a weakening of the reactivity and resistance of the body, including tissue immunity, lead to atypical development of connective tissue with the formation of an altered musculoskeletal structure - scars. They cause not only cosmetic, but also physiological disturbances [5-8].

Therefore, the problem of differential diagnosis and comprehensive rehabilitation treatment of head and neck scars remains an urgent problem of modern medicine.

\section{THE AIM}

Study of the influence of local oxygen deficiency on the features of the formation of keloid scars of the head and neck.

\section{MATERIALS AND METHODS}

The research material was 17 incisional biopsy specimens of keloid scars of different topographo-anatomical areas of maxillofacial localization, which were the highest age categories of patients from 19 to 63 years.

To achieve the established goals, the studied tissues were stained using the Mallory method, Hart + Van Gieson (in our modifications) and amydo-black (in our modifications) [9-11]. A digital camera was used for systematic documentation.

\section{RESULTS AND DISCUSSION}

Based on the literature, a visually keloid scar is characterized by a protruding part of the skin covered with the epidermis, under which there are hyaline masses $[12,13]$.

The histochemical studies were performed to determine the histochemical properties of fibrous structures of keloid scar. It was revealed that at coloring according to Mallory's technique, sections of fibrinoid swelling of collagen fibers were noted near central homogeneous hyaline masses. The latter were almost completely destroyed with the formation of fiber-fibrous structural elements, and in some areas the fibers and structural structures of the fibers were represented (Figure. 1).

The lateral areas of the dermis that adjacent to keloid scar tissue, at coloring by the Hart method, in our modification, 


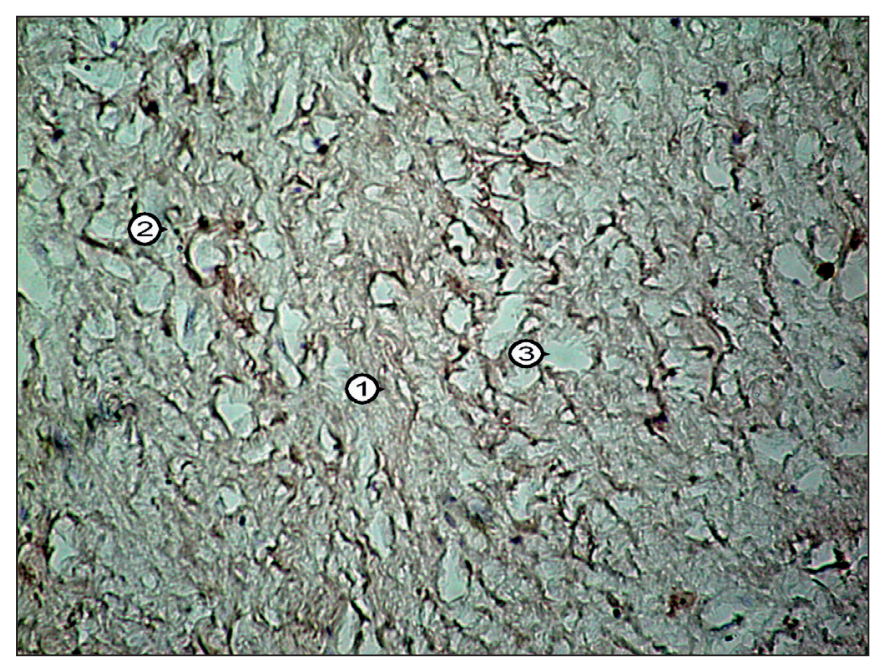

Fig. 1. Plots of fibrinoid swelling of keloid scar. Colored by Mallory. 0b.$:$ x 40: 0k .: $x 10$.

1-fragmented collagen fibers; 2-protein composites; 3-regressed vessels.

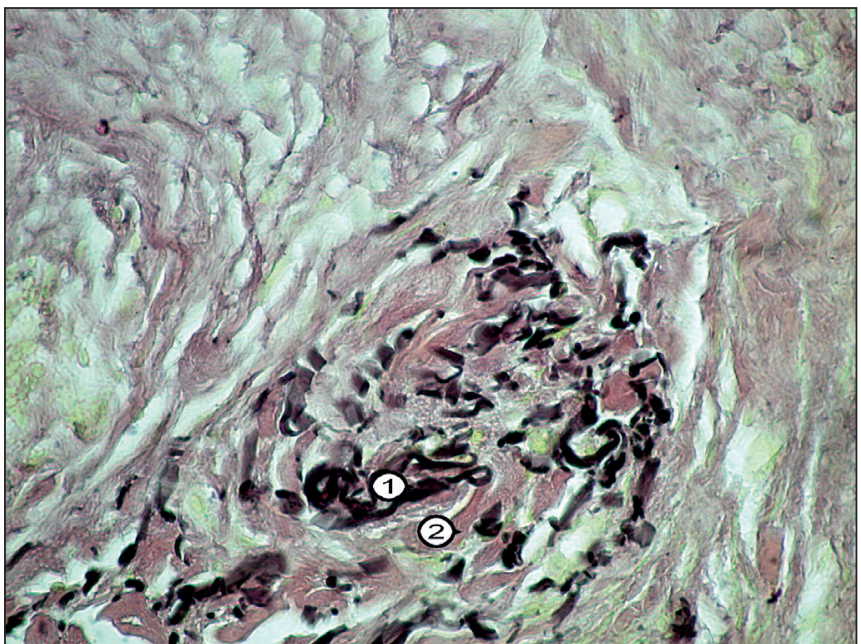

Fig. 3. The formation of a neuroma in the main zone of keloid scars. Colored by Hart (in our modification). 0b.: x 100: 0k .: x 10:

1-neuroma; 2-collagen fibers.

were characterized by the separation of the hyalinosis zone from the undamaged dermis by coarse bundles of elastic fibers that are colored in dark purple.

Hyperelastosis, that was observed in the lateral areas of the keloid scar, in our opinion, should be regarded as an adaptive-compensatory process for formation of hyalinosis.

It has been established that the basis of the keloid scar reaches the borders of dermis, which consists of coarse bundles of collagen fibers were painted in red color. These bundles were separated from each other by bundles of elastic fibers that were painted in dark purple.

Between the aforementioned fibrous structures it was noted the vascular bundle, which was represented by arteries and veins. In the arteries, the external and internal membranes were clearly defined, painted in purple.

The circular smooth muscle layer was located between the membranes, which was colored green. Unlike arteries,

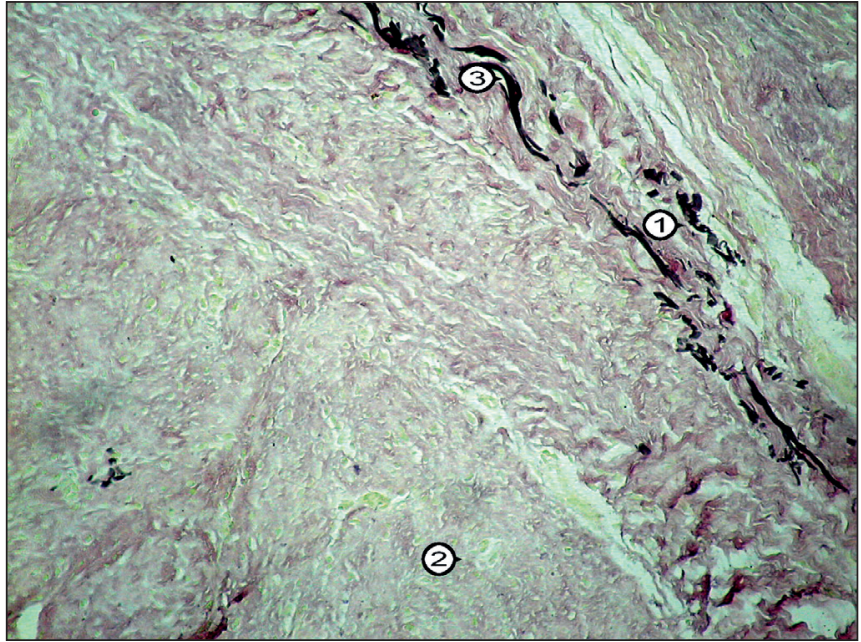

Fig. 2. Areas of the dermis that border to keloid scars. Colored by Hart (in our modification). 0b: $\times$ 20: 0k .: $\times 10$ :

1-intact dermis; 2-zone of hyalinosis; 3-elastic fibers.

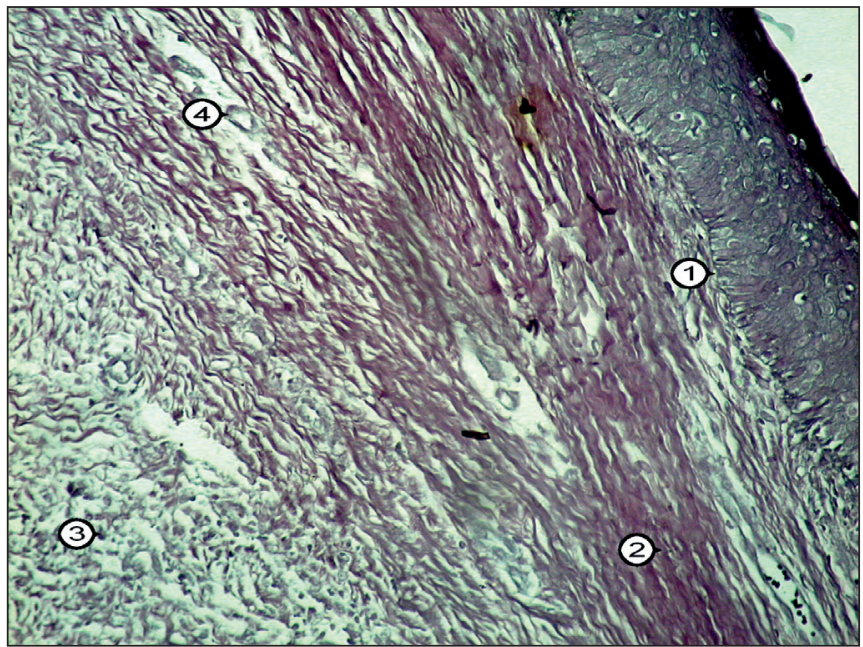

Fig. 4. Change of tinctorial properties of collagen fibers. Colored by amidoblack (in our modification). 0b .: 40: 0k .: x 10 .

1-basal membrane; 2-tinctorially modified collagen fibers; 3-core zone; 4-vascular components.

bundles of collagen and elastic fibers in the veins were intertwined.

It is obvious that precisely due to the presence of a vascular bundle in the basis of the keloid; a compensatory-adaptation process in the form of hyperelastolysis is carried out around it. The undifferentiated dysplasia of the connective tissue has caused the replacement and obstruction of single vascular components, which has complicated the local oxygen deficiency of keloid-altered tissues (Figure. 2).

It should be noted that in some cases the neuromas were visualized on serial histological sections at the base of the keloid scar at stained according to the Hart method, in our modification. The latter were represented by concentric, spiral-like myelin fibers, which were colored black. Between them bundles of collagen fibers colored in red were noted. In our opinion, the partial reparative regeneration of myelin fibers occurs is happened during the growth 
of the latter. Obviously, the presence of a neuroma in the thickness of the keloid scar falling under compression of collagen and elastic fibers causes the subjective sensations of patients (local pain, paresthesia and itching) (Figure. 3).

It was found that at coloring by amido-black, in our modification, in the areas of keloid scars adjacent to the epithelium, the papillary layer of the dermis was replaced by individual bundles of collagen fibers. The structure of the epidermis was preserved with the presence of horny scales.

Separate bundles of collagen fibers have stacked together and gradually have replaced the papillary layer, which included arcade microvessels. There were single cell infiltrations between bundles of collagen fibers. It was established that the keloid scar in case of this technique of coloring have consisted of thin fibrillar structures.

The bundles of fibrous structures during histological examination at coloring by amido-black were colored red due to changes in their tinctorial properties. In our opinion, a change in these properties when applying the above-mentioned color technique was due to the phenomenon of fibrinoid swelling.

Fibrinoid swelling, which was observed in keloid scars, has indicated its constant progression in the chronic course in the presence of various exogenous factors. Between the individual arteries and venules, there were light homogeneous structures of the protein deposit, among which there were single elongated fibroblast nuclei (Figure. 4).

Therefore, at the first stage of the formation of a keloid scar, a gradual replacement of the papillary dermis with bunches of collagen fibers, which were formed in case of presence of cellular infiltrates, was observed.

The second stage of keloid morphogenesis was characterized by fibrinoid swelling and necrosis of collagen fibers.

It should be noted that in conditions of progression of the keloid scar at its base, along with the phenomena of fibrinoid swelling of collagen fibers, plasma hemorrhage from the vessels was noted. The connective tissue hyalinosis was observed due to fibrinoid swelling and plasmoragia from blood vessels in the central zone of the keloid scar.

\section{CONCLUSIONS}

Thus, plasmaragia and the accumulation of protein deposits in the perivascular space determine the inhibition of local hemodynamics, which explains the decrease in oxygen transport to tissues. Decreased oxygenation and increased permeability of the vascular wall causes local hemocirculatory hypoxia. Therefore, in our opinion, to eliminate the local oil-deficient state, emoxipin should be used, which stabilizes the vascular wall and reduces tissue hypoxia by suppressing lipid peroxidation processes.

\section{REFERENCES}

1. Avetikov DS, Bukhanchenko OP, Lokes KP et al. Porivnyal'na kharakterystyka ekhohennoyi struktury pislyaoperatsiynykh normotrofichnykh ta atrofichnykh rubtsiv shkiry [Comparative characteristics of the echogenic structure of postoperative normotrophic and atrophic scars of the skin]. Klinichna khirurhiya. 2018; 85(5): 44-46. (in Ukrainian)
2. Avetikov DS, Bukhanchenko OP, Ivanytskyi I0 et al. Perspectives for applying the additional study methods for diagnostics optimization of postoperative hypertrophic scars of the head and neck. Wiad Lek. 2018;71(3 pt 1):470-473.

3. Avetikov DS, Buchanhenko OP, Shlykova OA et al. Presence of Type 1 Collagen Alpha-2 (COL1A2) (rs42524) Gene Polymorphism and Scar Tissue Formation in Different Areas of Head and Neck. Pesquisa Brasileira em Odontopediatria e Clínica Integrada. 2020; 20: e4422.

4. Ruksha TG, Aksenenko MB, Klimina GM, Novikova LV. Extracellular matrix of the skin: role in the development of dermatological diseases. Vestnik dermatologii I venerologii. 2013; (6): 32-39.

5. Gawronska-Kozak B, Grabowska A, Kopcewicz M, Kur A. Animal models of skin regeneration. Reproductive Biology. 2014; 14: 61-7.

6. Ogawa R. Keloid and Hypertrophic Scars Are the Result of Chronic Inflammation in the Reticular Dermis. Int J Mol Sci. 2017; 18(3): 606.

7. Ogawa R, AkaishiS. Endothelial dysfunction may play a key role in keloid and hypertrophic scar pathogenesis - Keloids and hypertrophic scars may be vascular disorders. Med Hypotheses. 2016; 96:51-60.

8. Paul S.P. Are incisional and excisional skin tension lines biomechanically different? Understanding the interplay between elastin and collagen during surgical procedures. IJBM. 2017; 7: 111-114.

9. Avilova 0, Marakushin D, Nakonechna 0, Gargin V. Microscopic features of the spleen under the influence of laproxides. Georgian Med News. 2018 Feb;(Issue):163-167.

10. Avetikov D, Loza K, Starchenko I et al. Experimental-Morphological Substation of Expediency to Use the Skin Glue Dermabond For Postoperative Wound Closure. Georgian Medical News. 2015;7-8(244245): 90-93.

11. Avetikov DS, Steblovskiy DV, Popovich IY et al. Izucheniye biokhimicheskikh svoystv kozhi sostsevidnoy oblasti pri vypolnenii kosmeticheskoy otoplastiki [Studying of biomechanical properties of skin in the mastoid region while the cosmetic otoplasty performance]. Klin Khir. 2015 Aug;(8):41-4. (in Russian)

12. Loza KO, Stavytskyi SO, Loza EO et al. Klinichna kharakterystyka stanu rubtsevo-zminenykh tkanyn shkiry pislya operatsiyi [Clinical characteristic of postoperative state of cicatricially-changed cutaneous tissues]. Klin Khir. 2016 Apr;(4):61-3. (in Ukrainian)

13. Moore AL, Marshall CD, Longaker MT. Minimizing Skin Scarring through Biomaterial Design. J Funct Biomater. 2017; 8(1): 3.

The work is a fragment of scientific research works of Ukrainian Medical Stomatological Academy of the Ministry of Health of Ukraine: "Diagnostic, surgical and medical treatment of patients with trauma, defects and deformities of the tissues, inflammatory processes of the maxillofacial localization»", state registration number 0119U102862 and a fragment of the research and development the Department of Paediatric Dentistry, State Higher Educational Establishment Uzhhorod National University "Comprehensive justification for providing dental care for children living in the area of biogeochemical deficiency of fluorine and iodine» (№ state registration 0119U101329).

\section{ORCID and contributionship:}

Kateryna P. Lokes - 0000-0002-8847-837X C,D

David S. Avetikov - 0000-0002-7055-3589 A, F

Oksana V. Klitynska - 0000-0001-9969-2833 D,E

Pavlo P. Brekhlichuk - 0000-0001-6754-5142 ${ }^{F}$

Yana I. Bun - 0000-0002-1792-9292 ${ }^{B}$ 


\section{Conflict of interest:}

The Authors declare no conflict of interest:

\section{CORRESPONDING AUTHOR}

\section{Kateryna P. Lokes}

Skovorody str. 1a, f. 4, 36000, Poltava, Ukraine

tel: +380509796778

e-mail: Lokes.ekaterina@gmail.com

Received: 17.01 .2020

Accepted: 05.03 .2020

A - Work concept and design, B - Data collection and analysis, C - Responsibility for statistical analysis,

D-Writing the article, E-Critical review, $\mathbf{F}$ - Final approval of the article 